This item was submitted to Loughborough's Institutional Repository (https://dspace.lboro.ac.uk/) by the author and is made available under the following Creative Commons Licence conditions.

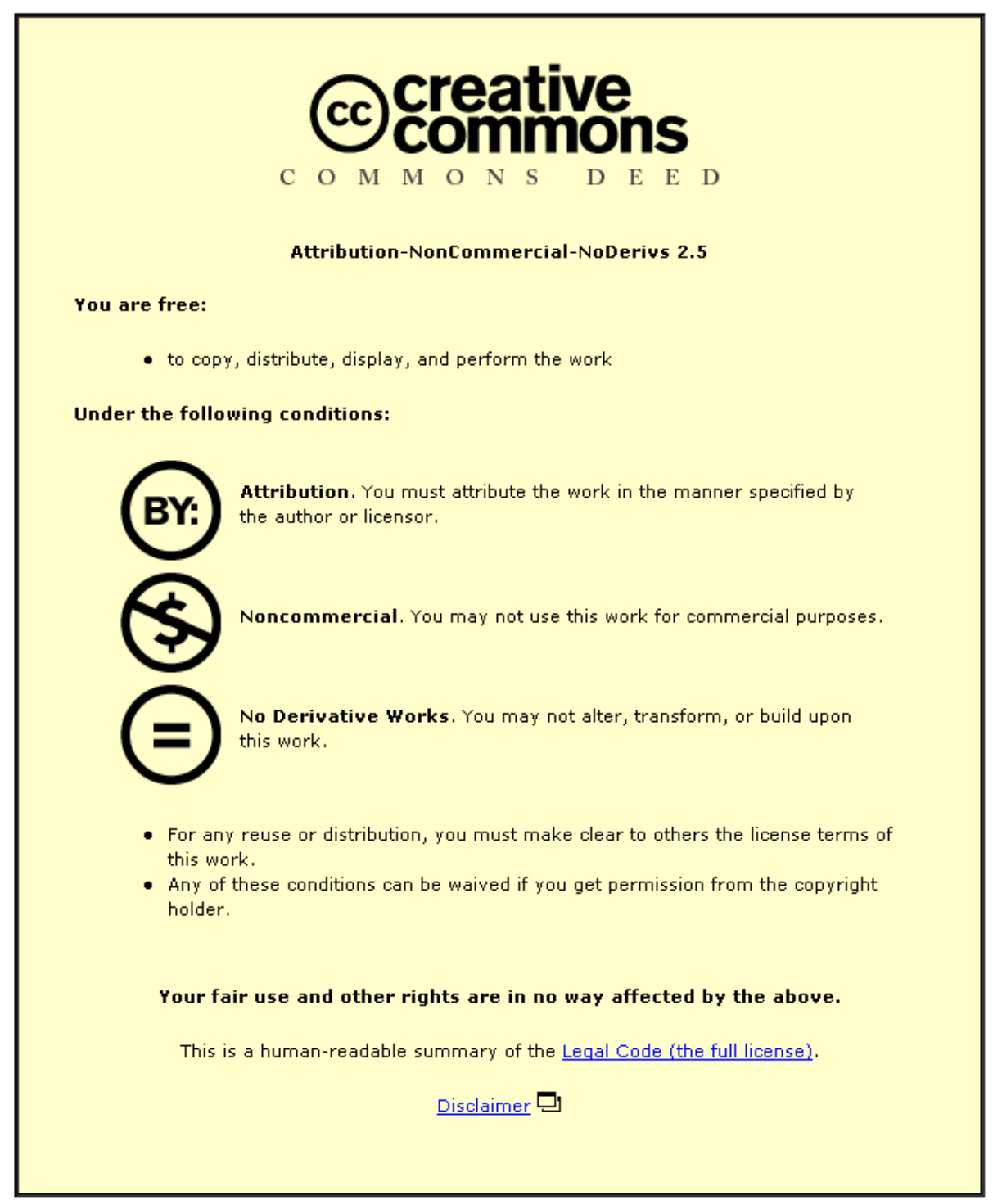

For the full text of this licence, please go to: http://creativecommons.org/licenses/by-nc-nd/2.5/ 


\section{Coupling utility performance targets with catchment management}

1 Joachim Ibeziako Ezeji MSc

$\mathrm{PhD}$ research scholar, Water, Engineering and Development Centre (WEDC), School of Civil and Building Engineering, Loughborough University, UK

2. Ian Smout MSC

Principal Programme Manager, Water, Engineering and Development
Centre (WEDC), School of Civil and Building Engineering,

Loughborough University, UK

3 Lee Bosher BSC, PGC, PhD

Senior Lecturer, Water, Engineering and Development Centre (WEDC), School of Civil and Building Engineering, Loughborough University, UK
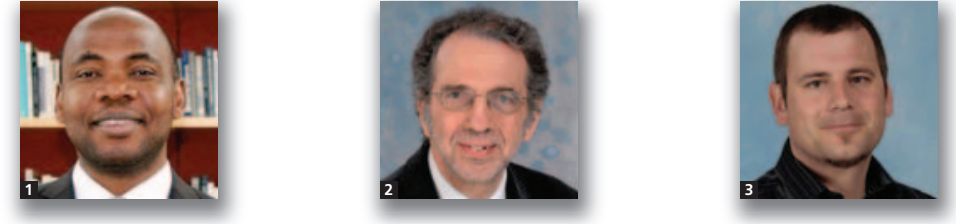

Institutional reform of state-owned water utilities serving urban areas has often set out to turn them into effective and efficient organisations, so that they can become excellent service providers. However, the pursuit of such objectives, which are often based on commercial targets, woefully ignores efficient catchment management. In view of this, this study reviews the case of the Cross State Water Board (CRSWB) Ltd in Calabar, eastern Nigeria. It identifies the serial neglect of the local watershed as a factor responsible for its operational and maintenance costs. It therefore argues for the need to develop and integrate catchment or ecosystem indicators into overall performance indicators currently used in setting and monitoring performance by the water utility as well as other utilities elsewhere, their owners or regulators. Such socio-ecological considerations as manifest in a catchment, according to the paper, are vital in building appropriate resilience against hazard risks such as flooding, land erosion, land inundation and salt water intrusion which currently plague the CRSWB, hence offering a bold and sustainable road map towards service efficiency and effectiveness for the growing urban population under a variable climate.

\section{Introduction}

The sustainability of utility water services in today's cities requires that they efficiently manage hazards, especially those associated with the living environment, climate change and an extensive range of other prevailing hazards that can impede efficient performance and service delivery of water. The importance of this is underpinned by the realisation that urban drinking water utilities such as the one in Calabar, Nigeria, generally provide piped water services, which commonly undergo extensive treatment to guarantee reasonable levels of safety. Based on this attribute, drinking water services provided by water utilities are regarded as improved. The concept of improved drinking water is defined as the water sources that by the nature of their construction are protected from outside contamination, particularly faecal matter (Unicef and WHO, 2012). In addition to piped household connections, in this category are public standpipes, boreholes, protected dug wells, protected springs and rainwater collection. Moreover, piped water on the premises, which is currently solely provided by water services utilities, is rated as the optimal service level (Unicef and WHO, 2012), since it provides the most convenient supply and has a positive impact on health and hygiene.

Water utilities must seek not only to meet their legislative requirements but also to maximise the availability, serviceability and life of their assets while minimising expenditure on energy, chemicals and processes (Hrudey et al., 2006). While they are under pressure to perform better, especially under the persisting demand for efficient services by an expanding urban population, even with less money (Danilenko et al., 2010) and a lean institutional capacity, there is a need for the utilities to understand and efficiently manage prevailing climatic and associated risks. Such risks include those emanating from socio-economic pressures, the terrain and the utilities' internal environment that may endanger the safety of this service through the degradation of natural ecosystems, infrastructure decay or lack of adequate maintenance and operation. Excellence in managing high impact risks and guaranteeing 
Coupling utility performance

targets with catchment

management

Ezeji, Smout and Bosher safe and efficient services is essential, not only to the bottom line and reputation of the utilities, but also to the well-being and prosperity of the cities and people the utilities serve.

Globally $1 \cdot 2$ billion people ( $23 \%$ of the world's population) live within $100 \mathrm{~km}$ of the coast (Small and Nicholls, 2003) and 50\% are likely to do so by 2030. In 200351 of the world's deltas had a combined population of 325 million (Syvitski, 2008), out of a global population of $6 \cdot 6$ billion (Bates et al. 2008) and this is predicted to increase rapidly through the growth of megacities such as Shanghai, Guangzhou, Bangkok, Yangon, Kolkata, Dhaka, Lagos, Ho Chi Minh City and Hanoi (Woodroffe et al. 2006). The water utilities that serve these coastal populations are exposed to hazards such as sea level rise, coastal erosion, flooding, salt intrusion and subsidence, as well as extreme high and low river discharges and changes in precipitation and evaporation. Adger et al. (2005) argued that an estimated 10 million people worldwide experience coastal flooding each year due to storm surges and landfall typhoons, and 50 million could be at risk by 2080 because of climate change and increasing population densities (Nicholls, 2004). The Unicef and WHO (2012) report reveals that between 1990 and 2008, the urban population in sub-Saharan Africa more than doubled and that, while overall urban water supply coverage levels have stayed just above $80 \%$, access to piped supplies decreased by 13 percentage points from $68 \%$ in 1990 to $55 \%$ in 2008. Nevertheless, over half the 126 million urban dwellers who did gain access to it did so through using piped supplies on the premises (42 million) and public taps ( 23 million).

Consequently, increasing the resilience of drinking water sources, particularly those tapped by water utilities in an environmental hotspot such as Calabar municipality, a part of the Niger River delta in eastern Nigeria, demands reducing their vulnerability to various risks, particularly those emanating from its catchments. In addition, for Calabar and other water supply utilities in the Niger Delta, a myriad of high impact risks such as the delta's low topography and an environmental setting that is susceptible to hazards, as well as the socio-economic risks of a rapidly sprawling urban population, urbanisation and the presence of large oil industries that often compromise and constrain water quality, makes risk management of water services critical. For example, urbanisation results in a range of socio-economic changes in addition to the movement of people to cities, as an increase in the urban population increases the demand for drinking and industrial water in urban centres (Molden, 2007) as well as the degradation of catchments. Most significant here is the burgeoning of unplanned residential and industrial areas in the sprawling urban centres of the Calabar catchment, which causes further stress.

Bates et al. (2008) suggest that both the quantity and quality of water resources are influenced by changes in land use, the construction and management of reservoirs, pollutant emissions and water or waste water treatment, and that water use is driven by changes in population, food consumption, the economy (including water pricing), technology, lifestyle and social views of water. A combination of these anthropogenic influences and extreme events coupled with climate change (including severe incidents of destructive floods, pollution and land erosion), is currently generating vulnerability and hazards in the Calabar catchment of the Niger Delta. This paper accordingly reports a study of these risks and the resulting consequence on utility operational costs and the utility's inability to meet their performance targets.

\section{Background}

\subsection{The Calabar catchment}

The city of Calabar is the capital of the Cross River State, Nigeria. It is a coastal city that lies on a peninsula formed by various creeks and rivers, especially the Calabar River, the Great Kwa River, the Cross River estuary and the Atlantic Ocean. However, the Calabar River system and the Great Kwa River system are the two major drainage systems in Calabar. The coastal plain sands (also known as Benin formation) of the Niger Delta are dominant in most parts of Calabar, although they are covered by thick overburden near the coast of the Atlantic Ocean. Calabar has been classified as having a subequatorial type of climate (Offiong et al., 2009). The maritime position of Calabar exercises a considerable ameliorating influence on its climate. The mean temperature is about $25^{\circ} \mathrm{C}$ with a range of about $8^{\circ} \mathrm{C}$. The annual rainfall exceeds $3000 \mathrm{~mm}$, most of which falls in the wet season from May to October. The relative humidity is high throughout the year, giving a mean annual figure of about $84 \%$. The vegetation of the area is mainly that of mangrove swamp, raffia swamp, cultivated vegetable gardens, numerous isolated stands of cultivated, semi-wild oil palm and coconut palm trees (Udo (1975) as quoted by Offiong et al. (2009)). Increases in population and urban expansion have altered land use and land cover, resulting in the rapid conversion of vegetated pervious cover to paved and impervious cover. This state of affairs has been brought about by large-scale agricultural, industrial and residential activities.

\subsection{The Cross River State Water Board Ltd}

The Cross River State Water Board Ltd (CRSWB) was incorporated in 1998 (Akpama, 2007; CRSWB, 2010). The company is wholly owned by the Cross River State government (CRSG). Its incorporation as a limited liability company called for total reorganisation and restructuring to enable it to be run and managed as a commercial enterprise. However, in mid2001 the CRSG recognised the need for expert management of the newly incorporated water company and its new facilities as well as turning it around. It therefore embraced reforms. A 
Coupling utility performance

targets with catchment

management

Ezeji, Smout and Bosher tripartite management type of public private partnership (PPP) contract was signed in December 2003 between Ortech Nig. Ltd (ONL) as the contractor, CRSWB as client and the CRSG as guarantor (CRSWB, 2007). The major policy objectives for utility reform at the CRSWB are improved water quality and quantity, reliability of water supply, an aggressive revenue drive and the continuous expansion of the water supply to meet increasing demand (CRSWB, 2007). These policy objectives also summarise the performance targets of the utility (especially the private sector partner). The role and functions of the private sector partner, ONL, were spelt out as follows by the CRSWB (2007).

- Undertake the PPP management contract for an initial period of 3 years and prepare the CRSWB for an eventual transition to a full concession.

- Provide specialist personnel to manage the operations of CRSWB such as production transmission, distribution, billing, revenue collection and commercial operations.

Provide reliable customer service and water coverage with the optimal use of resources.

- Take all steps necessary to achieve the agreed performance objectives by maximising water production and revenue generation.

Provide training and development opportunities for selected CRSWB staff.

- Propose and recommend improvements and changes to the operational policies and procedures of CRSWB.

- Propose and recommend adjustments to tariff schedules and other charges for water services.

CRSWB (2007) shows that the partnership contract was signed by ONL on the basis of two points of agreement, one of which was the provision of 5000 house connections by a separate contractor under the African Development Bank procurement procedures (called Lot 5). These connections were to be completed by the first year of the PPP operations but for various reasons work did not proceed as scheduled. Records showed that at the end of the Lot 5 contract there had been many delays, quality deficiencies and unsold connections.

The role and functions of the public sector partners (CRSWB and CRSG) consist of

setting tariffs and consultations with the private partner on tariff changes

allowing the private partner to manage the agreed functions of the CRSWB without interference

managing executive division functions

assigning relevant assets to the private sector partner

- assigning relevant CRSWBL personnel to the private partner

paying the salaries of the CRSWB staff retaining full ownership of all assets assigned to the private sector partner

- setting conditions of employment for CRSWB staff and disciplinary action.

However, even though CRSWB is required to operate commercially by relying on revenues to fund its services, due to its insufficient customer connections (Akpama, 2007) and huge operational costs the utility is still dependent on state subsidies to keep running. According to CRSWB (2007) these subsidies are meant to cover its operations and maintenance costs as well as its capital costs.

\section{The research}

\subsection{Common hazards impeding performance targets}

In light of the shared roles between the private and the public sector partners, the research set out to ascertain how the roles and their inherent targets interrelate with risk management in the face of prevailing vulnerabilities in the surrounding catchment. The Delphi technique (Clayton, 1997) was adopted using an open-ended questionnaire administered to 27 utility experts, mostly engineers, scientists, technicians and management staff, to facilitate the generation of a wide array of response categories to the question: what natural hazards confront utility water supply services? The responses indicate that CRSWB is currently having difficulties with natural hazards associated with a changing climate. The issues that were identified (in order of decreasing severity) include iron contamination, land inundation, flooding, increasing operation and maintenance costs (especially costs for critical water production inputs such as chemical and laboratory reagents and fuel) and coastal erosion. The next most severe were the unstable annual rainfall, increasing rainfall intensity, salt water intrusion, changes in the watershed vegetation and ecology, and decreasing quality of surface water. The least severe were earlier water flows, land erosion, inaccurate climate models and planning difficulties, decreasing groundwater/aquifer recharge, sea level rise, land subsidence, damage to water supply facilities and landslides, and the submersion of water supply facilities.

The responses to the question 'What are the impacts of natural hazards on utility operations?' by these experts at the CRSWB yielded a set of responses unique to the utility and its catchment. The responses on the extent of the impact were categorised using the Likert scale that ranged from $1 \cdot 00-5 \cdot 00$, with $1 \cdot 00-1 \cdot 49$ indicating no impact; $1 \cdot 50-2 \cdot 49$ indicating negligible impact; $2 \cdot 50$ 3.49 indicating moderate impact; $3 \cdot 50-4.49$ indicating a major impact and 4.50-5.00 indicating an excessive impact, as shown in Table 1.

Table 1 shows that militancy and vandalism (though a problem in the larger Niger Delta) has no impact on the operations of the 
Salt water intrusion

Increasing urban

demand for water

Decreasing surface

water quality

Unstable annual

rainfall

Iron contamination

Land inundation

Flooding
Increasing operation and maintenance costs Increasing rainfall intensity ( $\mathrm{mm} /$ hour) Land erosion

Changes in watershed vegetation Inaccurate climate modelling and planning difficulties Submersion of water supply facilities Coastal erosion

Landslide

Earlier water flow

Rain storm
Damage to water supply facilities Sea level rise Reduced stream/ river flows Inadequate financial resources Ocean surge
Decreasing Militancy and groundwater/aquifer vandalism recharge

Land subsidence

Customer

dissatisfaction

More concentrated water flows

Table 1. Respondents quantifying the impacts of risks on the utility's operations

CRSWB, while decreasing groundwater/aquifer recharge, land subsidence, customer dissatisfaction and more concentrated water flow all had a negligible impact. The impact of these hazards was analysed on the basis of cost, quality and time. This approach is in agreement with Zhou and Chen (2003) who state that the typical evaluation criteria of business process performance are cost, time and output quality, requiring that every business-process-related risk analysis should address these three elements. For a water services utility these three elements are vital in analysing the inherent risks.

\section{$3 \cdot 2$ Vulnerability}

In the context of urban water utility services, vulnerability could be defined as a utility's inability to withstand persisting adverse stressors and shocks. A utility's vulnerability in this context means the risk of having its services constrained as a result of a degraded catchment or a malfunctioning infrastructure as well as by excessive operational costs. Given that utilities often lack the financial capacity to invest in substantial infrastructure replacement programmes, they may continue to operate fully depreciated assets for 20-50 years after the point when a replacement should have occurred (Danilenko et al., 2010). When conditions of vulnerability are effectively addressed, potential risks are eliminated and the capacity to operate and function optimally increases. A degraded catchment is vulnerable to potential disaster, which impacts the utility's operations when extreme biophysical events, such as high intensity rainfall, occur. To determine CRSWB vulnerability in the context of climate variability the sample mean scores of the experts' responses were recorded against the questions, as shown in Table 2.

The mean scores here are indicative of the extent of vulnerability based on the variables used. These variables are not exhaustive but have largely been designed to cover as many attributes as possible within and outside the utility while being capable of influencing its plans for managing hazards. Higher

The limited run-off capacity of drainage system induces flood

Absence of effective leadership in the utility 
Coupling utility performance

targets with catchment

management

Ezeji, Smout and Bosher scores are indicative of higher levels of vulnerability. Variables with mean scores of 5 in an ordinal scale of 1-5 impose the greatest level of vulnerability on the utility in the context of this study.

\subsection{Use of critical inputs to improve water quality} According to the CRSWB (2009) the estimated daily water production up till 2012 was about $14357 \mathrm{~m}^{3} /$ day and water lost in the treatment process is consistent at an average of $1 \cdot 5 \%$. Since the PPP began in 2004, not many incidents of stoppage have been reported; however, between the period January 2006 and December 2011 water production was interrupted on about 23 separate days and on half these days there was no production from the Ediba Qua plant. This led to shortages in Calabar municipality as supplies were not delivered to the customers of the utility. The cause of this lost production was either delays in the supply of critical inputs or damage to the raw water main by various contractors (building and road construction). CRSWB (2007) defines critical inputs in water production as items used on the line to produce and pump water, without which it would be impossible to produce water. These items were listed as chemicals (alum, lime and chlorine), diesel fuel and lubricants, electric power from either the public supply or diesel-powered generators, and other essential equipment associated with maintenance and spare parts.

The World Bank credit also included an allocation for the procurement of critical inputs and this has been in place since the credit became effective (CRSWB, 2007). Since then, the critical inputs have been procured by the CRSWB's project implementation unit, but only upon requisitions made by the CRSWB operations division under the management of ONL. This arrangement is generally criticised as being cumbersome because it delays their supply from time to time. As a result, on a number of occasions it has been necessary to stop water production because of the shortages of one of the critical inputs (CRSWB, 2007). A further constraint on production includes occasional delays in procuring diesel where inadequate stocks are maintained. There are also some reported cases of robbery of these items, although stringent store control measures are in place in the operations division.

It was noted that calcium hypochlorite and sodium hypochlorite (otherwise known as liquid chlorine) are used interchangeably in the production process (CRSWB, 2007). Although sodium hypochlorite is the preferred agent, there have been reports of occasional national shortages and delays in procurement (they are currently not locally produced), hence allowing the utility the option of switching over to and using calcium hypochlorite in order to guard against production stoppages or even pumping untreated water (CRSWB, 2007). The use of these production chemicals is efficiently managed, and records show that dosage rates are always reviewed on a daily basis to meet Nigeria's water quality standards. Moreover, ONL often independently conducts a series of water quality tests to verify the dosing rates (CRSWB, 2007). The results from some of these tests have led to the review of the dosage rates as well as the updating of the water laboratory's organisation and procedures accordingly (CRSWB, 2007).

\section{Discussion}

In the context of this study, a hazard is defined as the expressions of the earth's physical processes (Unep and UNISDR, 2007) and vulnerability is defined as the state of susceptibility to harm from exposure to stresses associated with environmental and social change and from the absence of capacity to adapt (Adger, 2006). In accordance with these definitions, it can be argued that a disaster such as a flood is not a random occurrence and does not occur by accident. Instead, it is the result of the convergence of hazards and vulnerable conditions (See Unep and UNISDR, 2007). Thus, in a risk-sensitive utility, awareness of the catchment is crucial.

A forested catchment often reduces storm run-off, stabilises stream banks, shades surface water, cycles nutrients and filters pollutants (Furniss et al., 2010), but when it is degraded or deforested it loses these functions. For the CRSWB, data obtained from the respondents indicates a degraded catchment, with details in Table 3 showing the rising financial implications in percentage terms over a period of 7 years (2005-2011).

Reacting to its degraded catchment, CRSWB has built a new water treatment plant. In contrast, the water utility serving New York City, for example, satisfies the needs of more than 10 million people by tapping water from the Catskill and Delaware catchments, which are $90 \%$ forested (Furniss et al., 2010). To date, this has enabled the city to avoid substantial water treatment costs (Germain et al., 2007).

The contrast is significant, considering that River Okoi, where the CRSWB taps its raw water, originates within the tropical rainforest that transcends Nigerian borders via the Cross River State into the Republic of Cameroon. However, between 2000 and 2005 Nigeria ranked first amongst the ten worst countries for deforestation rates globally, losing over $55.7 \%$ of its primary forest in just 5 years (FAO, 2005). Logging, subsistence agriculture and the collection of fuel wood are cited as leading causes of forest clearing in Nigeria. A study by the Trust for Public Lands and the American Water Works Association shows that a $10 \%$ decrease in forest cover in a catchment can increase water treatment and chemical costs by as much as $20 \%$ (Ernst, 2004). This captures the threat posed to water quality by a catchment dominated by agriculture, industries and housing. 


\begin{tabular}{|c|c|c|c|c|c|c|}
\hline Year & Aluminium sulphate: \% & Hydrated lime: \% & Chlorine (liquid/gas): \% & Chlorine (powder): \% & Diesel: \% & PHCN: \% \\
\hline 2005 & $2 \cdot 5$ & 3 & 5 & 5 & 15 & 2 \\
\hline 2006 & 5 & $6 \cdot 1$ & 5 & 7 & 20 & 5 \\
\hline 2007 & 8 & 7 & 15 & 10 & 23 & 5 \\
\hline 2008 & 12 & 10 & 20 & 12 & 26 & 5 \\
\hline 2009 & 15 & 12 & 23 & 20 & 28 & 9 \\
\hline 2010 & 25 & 25 & 25 & 26 & 30 & 12 \\
\hline 2011 & 27 & 30 & 30 & 29 & 35 & 15 \\
\hline
\end{tabular}

Source: Author's adaptation of CRSWB (2009) and other literature. PHCN: Power Holding Company of Nigeria

Table 3. Annual percentage increase of expenditure on critical inputs of the Calabar water supply system

Aquifers in Calabar are not even faring better, with household refuse and small-scale enterprises such as workshops, markets, petrol stations and hospitals dominant in their catchment, constituting potential sources of pollution (Edet, 2004). Despite this, no ongoing collaboration exists among important stakeholders in the local catchment to address the situation. Yet these catchments and their wetlands are supposed to serve as a buffer zone to the local rivers. When the buffering functions of a catchment are lost, flooding is often the consequence. For a river delta the effect of this change is dramatic. The resulting changes in vegetation cover and soil characteristics can increase flooding and mass wasting, causing severe impacts on downstream infrastructure and aquatic ecosystems (Istanbulluoglu et al., 2004; Miller et al., 2003). From the questionnaire, the high mean score of 4.38 indicates the respondents' strong agreement that persistent changes in land use in their catchment is a problem. Here, forests that once provided high quality run-off in the catchment have largely become developed parcels that adversely influence the run-off pattern and water quality. Moreover, in Calabar flooding induces turbidity and often acts in tandem with land erosion. Turbidity indicates the presence of suspended clay, silt, finely divided organic matter, algae and other microorganisms in the water; hence contaminants easily find their way into surface water sources as constituents of turbidity. Also, high turbidity interferes with chlorination and makes the water unsuitable for human consumption (Dearmont et al., 1998). The rising cost of critical inputs operates in tandem with the rising degradation of water quality and this affects the overall production time.

The focus here is the poor quality of water from the catchment and the resulting requirement for high expenditure on power and chemicals in water treatment processes to remove and destroy bacteria and other pathogens. As a surface-waterdependent utility, CRSWB needs to overcome high levels of microbial pollution commonly associated with sources such as rivers, streams, lakes and ponds.

The cost of hazards in a typical catchment includes financial as well as social and ecological costs. The issue of cost is strategic because costs traditionally influence most internal corporate decisions, whether they relate to financial, social or environmental performance (Adams et al., 2007). Therefore, quality analyses need to be supported with relevant cost implications at source (primary) as well as the intermediate and downstream stages. This supports Hamilton et al. (2006) who note that managing risks to water safety requires more than the identification of hazards and their control points, as the process requires an integrated and complete view of the vulnerabilities to the system from catchment to tap. However, the axiom 'prevention is better than cure' has prominence here.

The socio-ecological costs of climate change or extreme events for a water utility, if poorly managed, are capable of putting it out of business or significantly raising the cost of water. A typical catchment has the potential to impose or burden the utility with all the four central risks that comprise enterprise risk management - hazard, finance, operational and strategic. According to the Casualty Actuarial Society, as quoted by D'Arcy (2001), enterprise risk management is 'the process by which organizations in all industries assess, control, exploit, finance and monitor risks from all sources for the purpose of increasing the organisation's short and long term value to its stakeholders'. The need to attend to these risks is crucial because of their concurrent or ripple nature. A hazard has the tendency to act in combination or generate or move in tandem on a particular point at different scales. As noted in the study area, utility risks could be argued to stretch beyond the water safety plan, as they involve the breakdown of utility facilities, the shrinking of utility profit, the imposition of a regime of 
higher operation and maintenance as well as water shortage events; all issues that are summarised in Table 4.

However, substantial cost can possibly be saved by the prevention of upstream hazards. Degradation of water catchments undermines investments already made in water resources, as loss of vegetation, erosion and sedimentation are major threats to surface water resources because they cause lower base flows and higher flood peaks (Foster and BricenoGarmendia, 2010). In terms of water treatment, a potential problem is posed by flooding or river spate conditions that may have a domino effect in reducing the effectiveness of treatment barriers in succession, and rapidly deteriorating raw water quality presents complications for operators trying to maintain optimal coagulant dosing, which in turn can lead to suboptimal filter performance and increased demand for chlorine (Hamilton et al., 2006).

Utilities have a choice to be either proactive (and reap the accompanying gains) or reactive (and suffer the accompanying losses). This underscores the centrality of strategic catchment management in setting performance targets. However, for CRSWB it was noted that, while land erosion, flooding and changes in catchment vegetation advance, the corresponding finance to mitigate them recede. CRSWB has no budgetary allocation for its catchment management. This is in the face of rising operational costs associated with operators' overtime as a result of high turbidity as well as energy and chemical use. Exacerbating these rising water treatment costs are associated costs of energy, manpower and other non-chemical costs. This is consistent with research in the USA by Dearmont et al. (1998) who note that the total costs of turbidity and chemical contamination would likely be higher if non-chemical costs were considered.

There is a need for CRSWB to act in collaboration with federal agencies and other sister state government agencies to design new laws and enforcement mechanisms as well as instituting surveillance required to confront emerging challenges. For example, climate adaptation measures in a typical catchment could possibly rely on maintaining and improving catchments because healthy, resilient catchments are more likely to support desired ecological services in the face of climate change (US GAO, 2007), including good quality water. The importance of assessing and being sensitive to these extra costs implications has been recognised internationally in the 1992 Dublin statement

Dublin Principle No. 1. Fresh water is a finite and vulnerable resource, essential to sustain life, development and the environment: Since water sustains life, effective management of water resources demands a holistic approach, linking social and economic development with protection of natural ecosystems. Effective management links land and water uses across the whole of a catchment area or groundwater aquifer. (WMO, 2012)

Also, it is argued that time is at the heart of the effectiveness in water services by the utilities. Impacts linked to time could be said to be a high risk as they often move in tandem with cost. A clear evidence of the high risk impacts on time is the prevailing intermittence of supply in Calabar and elsewhere in Nigeria, which is largely responsible for the scorn in which the public holds public utilities. CRSWB Ltd, as at the time of this study in late 2011, does not supply water on a 24/7 time basis. Factors identified as being responsible consist of limited revenue or financial resources to keep on top of critical inputs such as chemicals and the non-availability of electricity or energy with which to maintain and operate services at optimal levels. Moreover, the overwhelming penchant and drive for the attainment of commercial goals often act against sustainability. This is largely because sustainable approaches seek to change the contemporary global emphasis on economic capital at the expense of the world's natural and social capital (Adams et al., 2007). According to the United Nations Conference on Trade and Development (Unctad, 1996) as quoted by Adams et al., (2007), the world's natural and social capital is often considered free and therefore ignored in terms of economic value and the gain or loss of natural and social capital.

Current developments in the water sector, especially actions to offset or adapt to the hazards of climate change, for example, may need to overcome the weakness inherent in these approaches, and the related tunnel vision by adopting a coupled socio-ecological approach (Berkes and Folke, 1998)

\begin{tabular}{llll}
\hline Sign of stress & Stress & Indicator & Risk \\
\hline High chlorine demand & Ecological & Degraded catchment & Hazard/financial \\
High budgetary expenditure on power & Energy & Regular public power supply failure & Financial \\
High non-revenue water & Operational & Degraded infrastructure & Financial/social/reputational
\end{tabular}

Table 4. Common indication of utility stresses in the Calabar water supply system 
Coupling utility performance

targets with catchment

management

Ezeji, Smout and Bosher that exposes the vulnerabilities and risks latent in them. Based on this consideration, managing or controlling hazards requires the effective collaboration and integration of efforts in interdisciplinary boundaries. Setting up thresholds and monitoring indicators to safeguard against exceeding such a threshold are important if resources are not to be wasted. Therefore, a threshold needs to be set for all the major indicators used in assessing or evaluating a utility. The effective monitoring of such thresholds offers an enhanced chance of limiting the negative impacts of natural hazards. Resilience is the capacity of a utility to withstand and/or absorb interruptions and still function as if nothing severe has happened. A resilient water services utility is one that is able to maintain its character and values over an appropriate time span in terms of corporate objectives, vision and mission. Therefore, the enhanced performance of public water utilities is dependent not merely on utility reform in whatever form, be it commercialisation or privatisation, but also on environmental accountability targets that could be underpinned by indicators similar to those already in use in the sector, for instance, indicators used in assessing performance such as working ratio, percentage of service coverage or nonrevenue water. Therefore, this study in furtherance of the desired paradigm shift proposes

catchment indicators such as land use and protection, source water quality and flow variation/extremes

- water use indicators such as abstraction rate, billing data and supplied water quantity.

\section{Conclusion}

A water utility's financial commitment to quality control (inhouse water treatment processes) is likely to be a great burden if no serious commitment is extended to quality assurance (as represented by a well-managed and monitored watershed or catchment). Effective quality assurance via enhanced catchment management is likely to reduce the burden of complexity, unaffordability, unreliability and lack of skills that goes with the demands of water treatment as a result of a range of hazards. Maintaining and improving the watershed to safeguard water quality is cost-dependent although it saves cost in the long term. Attempts to achieve water quality need to start from the watershed, or the consequence of neglect could be huge due to increased daily expenditures on chemicals. Appropriate investment in watershed monitoring could possibly leverage risk assessments in a watershed. Such assessments, using for example meteorological monitoring as well as stakeholder interviews and feedbacks, could become important components in decision-making, especially on ways to mitigate and eliminate the occurrence of hazards. For example, an investment in monitoring source water quality through rigorous daily quality tests or water levels using monitoring wells could be cost-effective in the long term. A forested and well-managed watershed could help reduce and mitigate incidents of flood, while reduced pressures on groundwater supplies could check pollution from salinity. Both roles need to be facilitated by the utilities and their regulators. Watershed management may be multi-institutional but utilities could have a facilitating role to play if they are to access good quality raw water and the attendant benefits, chief of which is a reduced treatment cost. It is hoped that by adopting this approach, water utilities in Nigeria (and ideally further afield) may become not only more efficient but also more sustainable service providers.

\section{REFERENCES}

Adams C, Frost G and Webber W (2007) Triple bottom line: a review of the literature. In The Triple Bottom Line: Does It All Add Up? Assessing the Sustainability of Business and CSR (Henriques A and Richardson J (eds)). Earthscan, London, UK, pp. 45-54.

Adger WN (2006) Vulnerability. Global Environmental Change 16(3): 268-281.

Adger N, Hughes T, Folke C, Carpenter SR and Rockstrom J (2005) Social-ecological resilience to coastal disasters. Science 309(5737): 1036-1039.

Akpama MA (2007) Assessment of the Institutional Framework for Water Supply and Sanitation Provision in Cross River State. Water Supply and Sanitation Sector Reform Programme Consultancy Services, report DF1, pp. 2-7.

Bates BC, Kundzewicz ZW, Wu S and Palutikof JP (eds) (2008)

Climate Change and Water. Technical paper of the Intergovernmental Panel on Climate Change, IPCC Secretariat, Geneva, Switzerland.

Berkes F and Folke C (1998) Linking social and ecological systems for resilience and sustainability: Introduction. In Linking Social and Ecological Systems: Management Practices and Social Mechanisms for Building Resilience (Berkes F and Folke F (eds)). Cambridge University Press, Cambridge, UK, pp. 2056-2107.

Clayton MJ (1997) Delphi: a technique to harness expert opinion for critical decision-making tasks in education. Education Psychology 17(4): 789-799.

CRSWB (Cross River State Water Board) (2007) Cross River State Water Board Ltd - National Urban Water Sector Reform Project (CRSWB/NUWSR) Report. CRSWB, Calabar, Nigeria.

CRSWB (2009) Cross River State Water Board Ltd Business Plan 2009. CRSWB, Calabar, Nigeria.

CRSWB (2010) Cross River State Water and Sanitation Policy, CRSWB, Calabar, Nigeria.

D'Arcy SP (2001) Enterprise risk management. Journal of Risk Management of Korea 12(1): 2345-2567.

Danilenko A, Dickson E and Jacobson M (eds) (2010) Climate Change and Urban Water Utilities: Challenges and Opportunities. Water Working Notes, Note no. 24. World Bank, Washington DC, USA.

Dearmont D, McCarl BA and Tolman DA (1998) Cost of water treatment due to diminished water quality: a case 
study in Texas. Water Resources Research 34(4): 849-853.

Edet AE (2004) Vulnerability evaluation of a coastal plain sand aquifer with a case example from Calabar, south eastern Nigeria. Environmental Geology 45(8): 1062-1070.

Ernst C (2004) Protecting the Source: Land Conservation and the Future of America's Drinking Water. The Trust for Public Land, American Water Works Association, Washington, DC, USA.

FAO (Food and Agriculture Organization of the United Nations) (2005) Global Forest Resources Assessment. FAO, Rome, Italy.

Foster V and Briceno-Garmendia C (eds) (2010) Africa's Infrastructure: A Time for Transformation. World Bank, Washington DC, USA.

Furniss MJ, Staab BP, Hazelhurst S et al. (2010) Water, Climate Change and Forests: Watershed Stewardship for a Changing Climate. Gen. Tech. Rep. PNW-GTR-812. USDA Forest Service, Pacific Northwest Research Station, Portland, OR, USA.

Germain RH, Munsell JF and Brazill K (2007) The New York City watershed model forests revisited five years later: an assessment of successes, failures, and challenges for the future. Journal of Extension 45(3): 267-278.

Hamilton PD, Gale P and Pollard S (2006) A commentary on recent water safety initiatives in the context of water utility risk management. Environment International 32(8): 958-966.

Hrudey SE, Hrudey EJ and Pollard SJT (2006) Risk management for assuring safe drinking water. Environment International 32(8): 948-957.

Istanbulluoglu E, Tarboton DG, Pack RT and Luce CH (2004) Modeling of the interactions between forest vegetation, disturbances, and sediment yields. Journal of Geophysical Research 109(F1), http://dx.doi.org.10.1029/2003JF00004.

Miller D, Luce CH and Benda LE (2003) Time, space, and episodicity of physical disturbance in streams. Forest Ecology and Management 178(1): 121-140.

Molden D (2007) Editorial: water responses to urbanization. Paddy and Water Environment 5(4): 207-209.
Nicholls RJ (2004) Coastal flooding and wetland loss in the 21st century: changes under the SRES climate and socio-economic scenarios. Global Environmental Change 14(1): 69-86.

Offiong RA, Atu JE, Njar GN and Amuyou UA (2009) Problems and prospects of poor drainage systems and urban sustainability in Calabar, Nigeria. Global Journal of Social Sciences 17(2): 121-127.

Small C and Nicholls RJ (2003) A global analysis of human settlement in coastal zones. Journal of Coastal Research 19(3): 584-599.

Syvitski JPM (2008) Deltas at risk. Sustainability Science 13(1): 23-32.

Unep and UNISDR (United Nations Environment Programme/ United Nations Office for Disaster Risk Reduction (2007) Environment and Disaster Risk: Emerging Perspectives. Unep and UNISDR, Geneva, Switzerland.

Unicef and WHO (United Nations Children's Fund and World Health Organization) (2012) Progress on Drinking Water and Sanitation Update. Unicef, Geneva, Switzerland.

US General Accounting Office (GAO) (2007) Climate Change: Agencies should Develop Guidance for Addressing the Effects on Federal Land and Water Resources. GAO-07-863. Washington, DC, USA.

WMO (World Meteorological Organization) (2012) The Dublin Statement on Water and Sustainable Development. See http://www.wmo.int/pages/prog/hwrp/documents/english/ icwedece.html (accessed 09/04/2012).

Woodroffe CD, Nicholls RJ, Saito Y, Chen Z and Goodbred SL (2006) Landscape variability and the response of Asian megadeltas to environmental change. In Global Change and Integrated Coastal Management: the Asia-Pacific Region; Coastal Systems and Continental Margins (Harvey N (ed.)) Springer, Berlin, Germany, pp. 277-314.

Zhou $Y$ and Chen $Y$ (2003) Project-oriented business process performance optimization. Proceedings of the IEEE International Conference on Systems, Man and Cybernetics 5: 4079-4084.

\section{WHAT DO YOU THINK?}

To discuss this paper, please email up to 500 words to the editor at journals@ice.org.uk. Your contribution will be forwarded to the author(s) for a reply and, if considered appropriate by the editorial panel, will be published as discussion in a future issue of the journal.

Proceedings journals rely entirely on contributions sent in by civil engineering professionals, academics and students. Papers should be 2000-5000 words long (briefing papers should be 1000-2000 words long), with adequate illustrations and references. You can submit your paper online via www.icevirtuallibrary.com/content/journals, where you will also find detailed author guidelines. 